(c) American Dairy Science Association, 2006.

\title{
Cell Turnover and Activity in Mammary Tissue During Lactation and the Dry Period in Dairy Cows
}

\author{
M. T. Sorensen, ${ }^{1}$ J. V. Nørgaard, P. K. Theil, M. Vestergaard, and K. Sejrsen \\ Department of Animal Health, Welfare and Nutrition, Danish Institute of Agricultural Sciences, \\ Research Centre Foulum, PO Box 50, DK-8830, Tjele, Denmark
}

\begin{abstract}
Milk yield of the dairy cow follows a pattern termed the lactation curve. We have investigated the cellular background for this pattern. Seven mammary biopsies were obtained from each of 10 cows: at the end of lactation (d 347, equal to $\mathrm{d} 77$ before next parturition); during the dry period at d 48 ( $4 \mathrm{~d}$ after dry off); $16 \mathrm{~d}$ before parturition; and during lactation at d $14,42,88$, and 172. The fraction of proliferating (staining positive for Ki-67) alveolar cells was higher during the dry period $(8.6 \%)$ than during lactation $(0.5 \%)$. The fraction of apoptotic (staining positive by terminal deoxynucleotidyl transferase-mediated dUTP nick-end labeling) alveolar cells was higher immediately after dry off $(0.37 \%)$ and in early lactation $(0.76 \%)$ than during other periods $(0.15 \%)$. The enzyme activities of fatty acid synthetase, acetyl CoA-carboxylase, and galactosyl transferase were approximately 12-, 11-, and 4-fold higher, respectively, during lactation than during the dry period. In conclusion, mammary cell proliferation is substantial in a period near parturition but otherwise low, and apoptosis is elevated at dry off and in early lactation. The increase in apoptosis in early lactation may be due to discarding nonfunctional or senescent cells or to removal of a surplus of newly synthesized cells. The activity of selected enzymes central for milk synthesis is probably not limiting for milk production.
\end{abstract}

Key words: dairy cow, enzyme activity, lactation and dry period, mammary cell turnover

\section{INTRODUCTION}

Milk yield of the dairy cow follows a pattern termed the lactation curve. Although the cellular background for this pattern is not well elucidated, it is generally accepted that the number of cells and the production capacity per cell are the main determinants of the milk production and that the declining phase of lactation

Received May 19, 2006.

Accepted July 14, 2006.

${ }^{1}$ Corresponding author: MartinT.Sorensen@agrsci.dk mainly is due to loss of mammary cells (Knight and Wilde, 1993). In pregnant dry dairy cows, there is a significant increase in cell proliferation from the early to late dry period as quantified by in vitro incorporation of ${ }^{3} \mathrm{H}$-thymidine (Capuco et al., 1997). In the lactating nonpregnant dairy cow, the rate of cell proliferation is exceeded by the rate of cell apoptosis leading to a gradual decrease in the total number of epithelial cells in the udder with advancing lactation (Capuco et al., 2001). Thus, in the dairy cow there is apparently no net mammary growth during lactation and the dry period is the time of renewal of the cell population. To our knowledge, there are no reports on cell turnover in dairy cows during a full lactation cycle. Cell turnover is greatly affected by the IGF system (Baumrucker and Erondu, 2000; Duan and Xu, 2005), but there are no published results on expression of genes in the dairy cow mammary gland belonging to the IGF system.

The production of milk requires enzymes catalyzing the synthesis of milk constituents. In the goat, Wilde et al. (1986) found that the activity of key enzymes catalyzing the synthesis of milk constituents increased during early lactation when milk yield was increasing and then leveled off after peak milk production. There was no decrease in the activity of key enzymes in late lactation. Comparable data are not available in the dairy cow.

The objectives were to describe the balance between mammary epithelial cell proliferation and apoptosis and to describe the activities of key enzymes catalyzing the synthesis of milk constituents during pregnancy and lactation in the dairy cow. Expression of selected genes and plasma concentrations of selected hormones were quantified to add understanding of the regulation of cell turnover and activity of mammary cells.

\section{MATERIALS AND METHODS}

\section{Animals and Diets}

Ten Holstein-Friesian cows of first to fourth parity from the herd at Research Centre Foulum were used and housed in tie stalls, milked daily at approximately 0600 and $1600 \mathrm{~h}$, and fed a ration based on grass silage 
and concentrate. The feeding regimen was ad libitum during lactation and restricted during the dry period according to Danish recommendations (Strudsholm et al., 1999). The cows were artificially inseminated according to herd procedure approximately at $\mathrm{d} 60$ (45 to 76) after parturition. Two cows were reinseminated at d 122 and 169, respectively. The cows were dried off 52 $\mathrm{d}$ before expected parturition.

\section{Sampling}

Seven mammary gland biopsies were obtained from each cow and subsequently analyzed. All biopsies were obtained from front mammary glands. The first biopsy was taken at the end of a lactation (d $347 \pm 21.3$ equal to $\mathrm{d} 77 \pm 1.4$ before next parturition); the next, during the dry period at d $48 \pm 1.5$ ( $4 \mathrm{~d}$ after dry off); then at d $16 \pm 1.6$ before parturition; and during lactation at d $14 \pm 2.9,42 \pm 2.7,88 \pm 1.8$, and $172 \pm 2.0$.

The cows were milked immediately before biopsy. Biopsy samples were collected with a ProMag 2.2 instrument and Ultra-Core II needles (Medical Device Technologies, Gainesville, FL). A point on a front mammary gland without visible blood vessels was marked and the skin was anesthetized by a subcutaneous injection of $2 \mathrm{~mL}$ of Xylocain $(20 \mathrm{mg} / \mathrm{mL}$ lidocain, AstraZeneca, Albertslund, Denmark). A successful biopsy contained $20 \mathrm{mg}$ of tissue, but in some instances the needle was empty. Two to 3 biopsies in the same incision per front gland were commonly taken. Biopsies from the 2 front glands were pooled. The majority of biopsy tissue was snap frozen immediately in liquid nitrogen and kept at $-80^{\circ} \mathrm{C}$ until analysis for enzyme activities and mRNA abundance. A small portion of tissue was used for immunohistochemical detection of apoptosis and cell proliferation, and was fixed overnight in $4 \%$ neutral buffered formalin, dehydrated, and embedded in paraffin according to standard techniques. Blood samples were obtained from the jugular vein and serum was harvested and kept at $-20^{\circ} \mathrm{C}$ until analyzed for hormones.

\section{Cell Proliferation and Apoptosis}

Slices $(4 \mu \mathrm{m})$ were deparaffinized and hydrated according to standard techniques. Cell proliferation was measured by localization of the proliferating cell nuclear antigen (PCNA) and Ki-67 proteins. Antibodies (Dako, Glostrup, Denmark) and a commercial immunohistochemical staining kit (EnVision, Dako) were used. The manufacturer's recommendations were followed. A commercial terminal deoxynucleotidyl transferasemediated dUTP nick-end labeling (TUNEL) kit (ApopTag, Oncor, Purchase, NY) was used to stain apoptotic cells. The manufacturer's recommendations were followed. Cell proliferation and apoptosis were quantified by evaluating 1,500 nuclei of alveolar cells.

The fraction of alveolar nuclei staining for PCNA was very high $(50 \%$ in early and $54 \%$ in late dry period; 27 to $35 \%$ during lactation). Apparently, PCNA cannot be used as a measure of cell proliferation when staining is based on the highly sensitive EnVision method, and consequently, data on PCNA staining will not be presented or discussed further.

\section{Enzyme Activities}

The activity of acetyl CoA carboxylase (ACC), fatty acid synthetase (FAS), and galactosyl transferase (GT) were assayed as described by Wilde et al. (1986) adjusted to small amounts of tissue. In the ACC assay, which is based on a catalytic reaction involving labeled substrate, there is an evaporation step in which the tissue homogenate is dried. The dried tissue homogenate was dissolved in scintillation solution and the radioactivity was counted. The measurable radioactivity increased linearly during the few days after ending the reaction, probably due to slowly dissolution of the dried tissue homogenate. Thus, the calculations were based on the radioactivity measured $48 \mathrm{~h}$ after stopping the reaction.

\section{DNA and RNA}

Concentrations of DNA and RNA were measured in tissue homogenates by fluorometric methods using commercial PicoGreen and SYBR Green kits (Molecular Probes, Eugene, OR), respectively, as described by Oksbjerg et al. (2000).

\section{Hormone Assays}

Bovine growth hormone (bGH) and insulin were assayed using time-resolved immunofluorometric assays and an AutoDELFIA fluorometer (Wallac, Turku, Finland). Bovine growth hormone was analyzed in a sandwich setup by 2 monoclonal antibodies, developed against synthetic bGH (Løvendahl et al., 2003). Insulin was analyzed in a sandwich setup using a modified DELFIA kit developed against human insulin and validated for bovine insulin (Løvendahl and Purup, 2002). Insulin-like growth factor-I was analyzed in a sandwich setup using time-resolved immunofluorometric assays (Frystyk et al., 1995) with use of a DELFIA 1234 research fluorometer (Wallac).

\section{Real-Time Reverse Transcription PCR}

Sample preparation and quantification of mRNA abundance was carried out as described by Theil et al. (2006a). Briefly, mammary tissue was homogenized 
Table 1. Accession numbers, amplicon location and length, range of threshold cycle $\left(\mathrm{C}_{\mathrm{T}}\right)$ values in samples, and slope of standard curve of the analyzed genes

\begin{tabular}{lllllll}
\hline Gene & Accession & $\begin{array}{l}\text { Amplicon } \\
\text { location } \\
\text { (exon-exon) }\end{array}$ & $\begin{array}{l}\text { Amplicon } \\
\text { length } \\
\text { no. }\end{array}$ & $\begin{array}{l}\text { Range of } \\
\mathrm{C}_{\mathrm{T}} \text { in } \\
\text { samples }\end{array}$ & $\begin{array}{l}\text { Standard } \\
\text { curve } \mathrm{R}^{2}\end{array}$ & $\begin{array}{l}\text { Standard } \\
\text { curve } \\
\text { slope }\end{array}$ \\
\hline ACC- $\alpha$ & NM_174224 & $29-30$ & 82 & $27-35$ & 0.996 & -3.68 \\
FAS & CA036000 & $35-37$ & 142 & $18-27$ & 0.999 & -3.27 \\
IGF-I & X15726 & $2-3$ & 123 & $29-38$ & 0.993 & -3.16 \\
Type I IGF rec. & X54980 & $11-13$ & 151 & $25-32$ & 0.993 & -3.85 \\
IGFBP-3 & M76478 & $2-3$ & 61 & $22-28$ & 0.995 & -3.07 \\
IGFBP-5 & S52657 & $3-4$ & 77 & $28-34$ & 0.998 & -4.06 \\
Lactoferrin & L08604 & $7-8$ & 101 & $15-27$ & 0.995 & -3.15 \\
Caspase-3 & AY575000 & $6-7$ & 167 & $30-39$ & 0.991 & -4.17 \\
18S rRNA & AY779625 & $1-1$ & 187 & $21-26$ & 0.998 & -4.08 \\
\hline
\end{tabular}

${ }^{1}$ ACC- $\alpha=$ Acetyl CoA carboxylase isoform $\alpha$ FAS $=$ fatty acid synthetase; IGFBP = IGF binding protein; Type I IGF rec. = IGF-I receptor $\beta$-subunit.

and RNA was purified using the RNeasy Mini kit (Qiagen, Crawley, UK). Purified RNA was reverse-transcribed using Superscript II RNase H reverse transcription kit (Invitrogen, Taastrup, Denmark) and a mix of random and oligo-dT primers; the cDNA were amplified with TaqMan Universal PCR Master Mix (Applied Biosystems, Naerum, Denmark) using probe and primers specific for each gene. The 18S rRNA (housekeeping gene) was detected using SYBR Green, whereas target genes other than lactoferrin were detected by minor groove binding probes. Probes were labeled with the FAM fluorophore on the $5^{\prime}$ end, whereas all primers were unlabeled. Primers were designed by using Primer Express version 2.0 software (Applied Biosystems; Table 1). Lactoferrin was detected with a locked nucleic acids probe (Roche Diagnostics, Hvidovre, Denmark). The response was quantified as cycle threshold $\left(\mathbf{C}_{\mathbf{T}}\right)$, the number of PCR cycles required to reach a certain threshold. The oligonucleotide sequences of forward primers, probes, and reverse primers for the genes are shown in Table 2.

The choice of housekeeping genes to standardize the outcome of real-time reverse-transcription (RT) PCR is a major issue of caution especially when analyzing in vivo samples (Bustin, 2002). Initially GAPDH and $\beta$ actin were tested, but transcription of these genes was significantly higher during the dry period compared with lactation (data not shown). In contrast, the abundance of $18 \mathrm{~S}$ rRNA was not significantly different between sampling days; hence, 18S rRNA was chosen for the purpose of normalization.

\section{Statistical Analysis and Calculations}

The statistical evaluation of cell proliferation and apoptosis was performed by use of the GENMOD procedure of SAS (SAS Institute, 1999) and data were assumed to be binomially distributed. The observations were dependent, because individual cows were sampled repeatedly, which was accounted for by the Generalized Estimating Equations approach and by incorporating a suitable defined random component. Standard contrasts were used for comparing differences between stages. Data were obtained as $\mathrm{C}_{\mathrm{T}}$ values (the cycle number at which logarithmic plots cross a calculated threshold line) to evaluate mRNA quantities according to the manufacturer's guidelines, and used to determine $\Delta \mathrm{C}_{\mathrm{T}}$ values $\left(\Delta \mathrm{C}_{\mathrm{T}}=\mathrm{C}_{\mathrm{T}}\right.$ of the target gene $-\mathrm{C}_{\mathrm{T}}$ of the housekeeping gene). Least squares means of $\Delta \mathrm{C}_{\mathrm{T}}$ values of target genes were normalized to the level observed at $\mathrm{d}-77$ by calculating the $\Delta \Delta \mathrm{C}_{\mathrm{T}}$ values $\left(\Delta \mathrm{C}_{\mathrm{T}}\right.$ observed at a given stage $-\Delta \mathrm{C}_{\mathrm{T}}$ observed at $\mathrm{d}-77$ ) and the relative mRNA quantity was calculated by using the formula: relative quantity $=2^{-\Delta \Delta \mathrm{C}_{\mathrm{T}}}$. All statistics were performed at the $\Delta \mathrm{C}_{\mathrm{T}}$ level (Theil et al., 2006a) to exclude potential bias because of averaging data that had

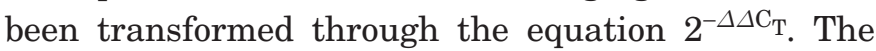
mRNA quantities, enzyme activities, DNA, RNA, and hormone concentrations were analyzed by using a normal mixed model (Littell et al., 1996), and repeated measurements within individual cows were accounted for by specifying a suitable random component. The covariance structure was modeled using spatial power option, which takes into account the different intervals between repeated measurements. The variables DNA, RNA, ACC enzyme activity, and hormone concentrations were transformed to natural logarithms, whereas FAS activity was transformed to square roots. Thus, data are presented as least squares means with $95 \%$ confidence limits. The contrast statement was used to provide comparisons between stages. Correlations are Pearson correlation coefficients on raw data.

\section{RESULTS}

The cows were healthy, although 4 were treated once for mastitis within $5 \mathrm{~d}$ of biopsy sampling. Eight cows 


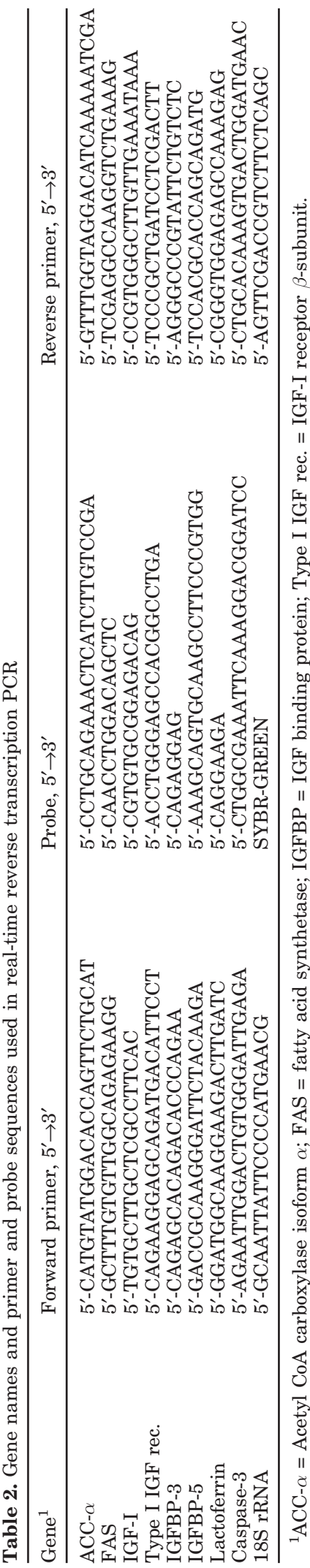

received a prophylactic antibiotic treatment at dry off. Milk yield was within the expected range and not affected by biopsy sampling (data not shown), and the cows can be regarded as a representative sample of the dairy cow population.

Cell proliferation as determined by the fraction of alveolar nuclei staining for Ki-67 was higher $(P=0.05)$ in late $(11 \%)$ than in early $(6 \%)$ dry period, and Ki-67 staining during lactation $(0.4$ to $0.9 \%)$ was lower $(P=$ 0.004 ) than during the dry period (Table 3 ). The fraction of alveolar nuclei staining positive in the TUNEL assay was higher $(P=0.04)$ in early $(0.37 \%)$ than in late $(0.17 \%)$ dry period. On $\mathrm{d} 14$ after calving, TUNEL staining was $0.76 \%$, whereas in the remaining lactation period it ranged between 0.08 and $0.25 \%$. The level of apoptosis $14 \mathrm{~d}$ after calving was greater $(P=0.007)$ compared with other sampling days (Table 3). When assuming that the duration time of apoptosis is $3 \mathrm{~h}$ (Bursch et al., 1990), the daily apoptotic rates were in the range of 0.6 to $6 \%$.

Concentration of DNA in mammary tissue increased $(P=0.01)$ in the dry period compared with late lactation (d -77) whereas it decreased $(P<0.001)$ throughout lactation (Table 3). The concentration of total RNA, which is traditionally regarded as an index of the protein synthetic capacity, was 1.7 -fold higher $(P<0.001)$ during lactation than during the dry period, but the concentrations did not differ within the dry period or within the lactation period (Table 3 ). The RNA to DNA ratio, which is traditionally regarded as a measure of synthetic capacity on a per cell basis, showed the same overall pattern as the RNA concentration although there was an increase $(P=0.005)$ from d 14 to 88 . Like RNA concentration, the enzyme activity can be regarded as a measure of the synthetic capacity of cells. The activity of ACC, FAS, and GT followed a general pattern; that is, low activity during the dry period, whereas the activity increased 11 -fold $(P<0.001)$ for ACC, 10 -fold $(P<0.001)$ for FAS, and 3 -fold $(P<0.001)$ for GT in early lactation compared with dry period levels (Table 3). The activity of ACC was constant during lactation. The activity of FAS increased $(P=0.02)$ from d 14 to 42; thereafter, it was constant. The activity of GT was constant from d 14 to 172 and decreased $(P<$ 0.001) in late lactation ( $d-77)$.

As expected, plasma concentrations of insulin and IGF-I were lowest in early lactation and highest in the dry period $(P<0.001)$, whereas GH concentration was higher $(P<0.001)$ in early lactation than in late lactation and in the dry period (Table 3 ).

For ACC- $\alpha$ and FAS, the abundance of mRNA was lowest $(P<0.001)$ during the dry period. The abundance of ACC- $\alpha$ mRNA increased $(P<0.001)$ from $d-16$ to 
Table 3. Mammary cell turnover, enzyme activity, gene expression, and hormone plasma concentration in dairy cows during the pregnancylactation cycle

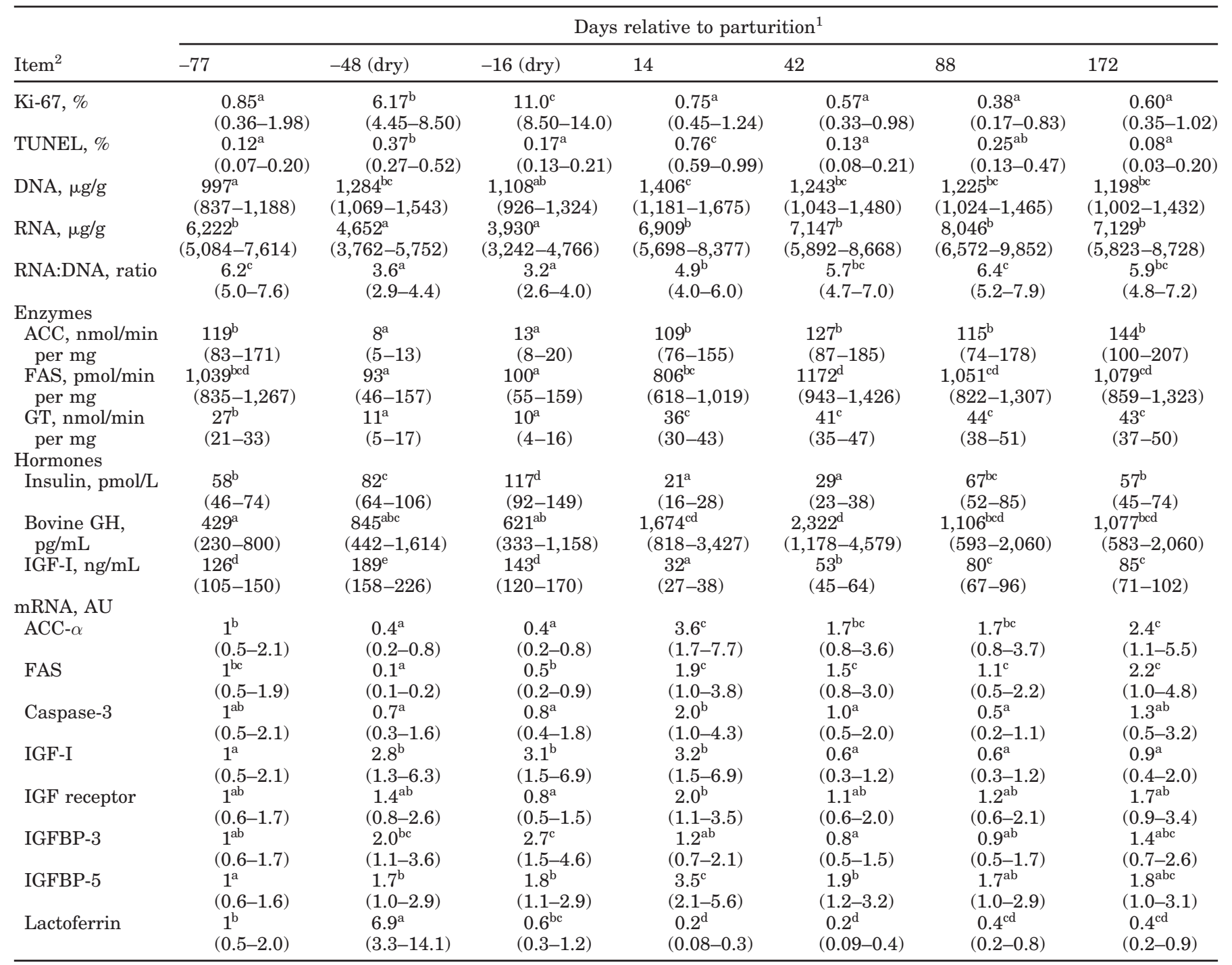

${ }^{\mathrm{a}-\mathrm{e}}$ Different superscripts within a row indicate significantly $(P<0.05)$ different means between days.

${ }^{1}$ Day -77 relative to parturition corresponds to d 347 of lactation; values are least squares means (95\% confidence limits in parentheses).

${ }^{2}$ TUNEL = Terminal deoxynucleotidyl transferase-mediated dUTP nick-end labeling (staining of apoptotic cells); Ki-67 = protein present in proliferating cells; ACC = acetyl CoA carboxylase; FAS = fatty acid synthetase; GT = galactosyl transferase; AU = arbitrary units; IGFBP = IGF binding protein; IGF receptor = Type I IGF receptor.

d 14 from parturition. The abundance of FAS mRNA increased 5-fold $(P=0.002)$ from d -48 to -16 from parturition and again 4 -fold $(P<0.001)$ from $\mathrm{d}-16$ to d 14 from parturition; thereafter, it remained constant $(P=0.36)$ throughout lactation (Table 3). Caspase-3 mRNA abundance at d 14 of lactation was 2 -fold higher $(P=0.005)$ compared with other sampling stages. There was no overall difference in caspase- 3 mRNA abundance between the dry and lactation period (Table 3).

The abundance of IGF-I mRNA was increased 3- to 5fold $(P<0.001)$ during the dry period and early lactation compared with mid and late lactation. The abundance of Type I IGF receptor mRNA was lowest at $d-16$ and it increased 2 -fold $(P=0.01)$ to $d 14$, at which point abundance was greatest (Table 3 ).

The abundance of mRNA for the 2 IGF binding proteins (IGFBP) did not show a similar pattern. Abundance of IGFBP-3 mRNA was high during the dry period compared with lactation $(P<0.001)$ and IGFBP-5 mRNA abundance increased 2 -fold $(P=0.001)$ at $\mathrm{d} 14$ compared with other stages. Lactoferrin mRNA abundance was greatest $(P<0.001)$ in the dry period at $d$ -48 from parturition ( $4 \mathrm{~d}$ after dry off) and lowest $(P<$ 0.001 ) in early lactation (Table 3 ). 


\section{DISCUSSION}

\section{Mammary Cell Turnover}

During the lactation period, cell proliferation was relatively low and constant, which is in agreement with the data of Capuco et al. (2001). In contrast, cell proliferation was generally high during the dry period and the highest measure was that closest to parturition, in agreement with the data of Capuco et al. (1997). Thus, cell proliferation seems to accelerate somewhere between 77 and $48 \mathrm{~d}$ before parturition. Because the last measure was taken $16 \mathrm{~d}$ before parturition, we do not know whether the high proliferation rate proceeds until term.

Apoptosis was significantly higher in early lactation than at any other stage, although there was an elevated level of apoptosis in the early dry period ( $4 \mathrm{~d}$ after dry off) based on TUNEL and caspase-3 results. A high level of apoptosis in early lactation was also found by Capuco et al. (2001). However, these authors speculated that their result was an effect of tissue edema and increased apoptotic leukocytes. We evaluated only mammary alveolar cells and are confident that the result is not an artifact. We hypothesize that increased apoptosis in early lactation may be due to death of nonfunctional or senescent cells or to removal of excess capacity of newly synthesized and yet undifferentiated cells.

Several genes are involved in cell turnover. Caspase3 and IGFBP-5 both have roles in apoptosis. Caspase3 gene expression peaked at $\mathrm{d} 14$ of lactation, coinciding with a peak in apoptosis. Except for this similarity in time of peaks, caspase-3 gene expression was not significantly correlated with TUNEL detection of apoptosis $(\mathrm{r}=0.18, P=0.18)$. This finding is in accordance with expression of caspase-3 in the goat mammary gland (Wareski et al., 2001).

Expression of the IGFBP-5 gene peaked at the same time as apoptosis, but there was no correlation between IGFBP-5 and TUNEL detection of apoptosis $(r=0.22$, $P=0.09$ ). Although depending on the ratio of IGFBP5 to IGF (Allan et al., 2004), IGFBP-5 is considered a proapoptotic factor in the mammary gland, where it has both IGF-I-dependent and IGF-I-independent effects (Allan et al., 2004). However, the complexity of IGFBP5 action is illustrated in a recent study on human osteoblasts in which inhibition of in vivo IGFBP-5 synthesis by IGFBP-5 knock-down resulted in increased apoptosis, whereas administering exogenous IGFBP-5 increased apoptosis (Yin et al., 2004).

The level of cell proliferation during the dry period was lower than that previously reported (Capuco et al., 1997), but with a similar pattern of increase from early to late dry period. During lactation, the rate of cell proliferation was constant at a relatively low level as was found by Capuco et al. (2001).

Among the genes involved in cell proliferation, expression of IGF-I, type I IGF-receptor, and IGFBP-3 in the mammary gland were evaluated. Gene expression of IGF-I was elevated during the dry period, supporting the role of IGF-I in stimulation of cell proliferation (Weber et al., 1999; Knight, 2000). Expression of the IGFI gene and the type I IGF receptor gene were high on d 14 of lactation, when apoptosis was high. This appears paradoxical, but may occur in support of survival of those cells that are not destined to undergo apoptosis. It should be noted that some genes are expressed in specific cell types within the mammary tissue; for example, IGF-I that is synthesized in mammary stroma and not in mammary epithelial cells (Baumrucker and Erondu, 2000). Because the proportion of stromal to epithelial cells changes over the lactation-pregnancy cycle (Capuco et al., 1997, 2001), the level of gene expression is not depicting the level in the particular cell type but rather the average for the tissue.

The pattern of mammary IGF-I gene expression was similar to that of systemic IGF-I concentration, with the exception that IGF-I gene expression was still elevated at $d 14$ of lactation when systemic IGF-I concentration had dropped. This exception in pattern may indicate that the mammary gland responds more slowly to negative energy balance than does the liver, which is believed to be a major contributor of IGF-I to the systemic pool (McGuire et al., 1992), and suggests that the mammary gland has a higher priority for nutrients than body tissue. Moreover, the local production of IGFI at d 14 of lactation is apparently not sufficient to stimulate mammary cell proliferation and our results indicate that systemic, rather than local, IGF-I is a main determinant for cell proliferation. This suggestion is in accordance with our observations in lactating sows (Theil et al., 2006b).

Gene expression of IGFBP-3 was low during lactation and increased during the dry period. This is in accordance with changes in the concentration of IGFBP-3 in blood and milk of cows (Baumrucker and Erondu, 2000). In primary bovine mammary epithelial cells, IGFBP-3 mRNA and protein levels show an IGF-I dose-dependent increase (Fleming et al., 2005). In accordance, we found a positive correlation $(r=0.60, P<0.001)$ between IGFBP-3 and IGF-I gene expression. Furthermore, IGFBP-3 gene expression had a pattern similar to that of cell proliferation $(\mathrm{r}=0.29, P=0.03)$, supporting a role of IGFBP-3 in cell proliferation (Weber et al., 1999).

The pattern of lactoferrin gene expression is in accordance with earlier observations (Goodman and Schanbacher, 1991). Lactoferrin has many functions and is involved in the immune system, induction of cellular 
growth and differentiation, and in cancer protection (Ward et al., 2005). Bovine lactoferrin binds IGFBP-3 and may act to free IGF from IGFBP-3 (Baumrucker et al., 2003). The significant peak in lactoferrin gene expression in the early dry period points to a significant role of lactoferrin at this stage in the immune system and perhaps in modulating IGF-I action.

Clearly, the effects of the IGFBPs may be complex. Depending on a variety of conditions they may inhibit or stimulate IGF-I action (Yin et al., 2004) or act as hormones themselves (Duan and $\mathrm{Xu}, 2005$ ). The results of the present study are consistent with a role for IGFBP-5 in apoptosis and a role for IGFBP-3 in proliferation or cell survival (or both) in the bovine mammary gland.

\section{Mammary Cell Activity}

The concentration of total mammary RNA, the RNA:DNA ratio, and enzyme activities, as well as gene expression of ACC- $\alpha$ and FAS, showed a pattern wherein these indicators of cell activity were low during the dry period and high during lactation. The increase in these indicators of cell activity from the dry period to early lactation may be due to an actual increase in activity of individual epithelial cells, but a change in the ratio of epithelial to stromal cells may also contribute to these changes as previously discussed. Milk yield per epithelial cell increases from early to peak lactation and remains constant throughout lactation (Capuco et al., 2001). Our data on enzyme activities and RNA:DNA ratio indicate an increase in cell activity in early lactation. But, this is not supported by data on ACC and FAS mRNA abundance showing that gene expression does not increase any further from d 14 after parturition. Whether an increase in these indicators of cell activity is due to increasing cell differentiation with advancing lactation or to a reduction in the number of low-producing cells after increased apoptosis in early lactation cannot be determined from the present study. However, a combination of the 2 scenarios is possible. Except for the activity of GT after peak lactation, the activity of the examined enzymes did not follow the pattern of the lactation curve; enzyme activities, therefore, do seem not to be limiting for the milk production as previously suggested (Nørgaard et al., 2005).

\section{CONCLUSIONS}

Mammary epithelial cell proliferation occurs mainly in a period around parturition and is low and constant during lactation. Apoptosis of mammary epithelial cells is high in early lactation perhaps due to discarding of nonfunctional or senescent cells or to removal of excess capacity of newly synthesized cells. The activity of enzymes did not closely follow the lactation curve and may not be limiting for milk yield. These results support the hypothesis that cell turnover is the major determinant for the shape of the lactation curve after peak lactation.

\section{ACKNOWLEDGMENTS}

The Federation of Danish Cattle Producers and the Ministry of Food, Agriculture and Fishery are acknowledged for financial support. The authors thank Helle Handll Christensen and Lars Bilde Gildbjerg for technical assistance and Ulrich Halekoh for statistical advice.

\section{REFERENCES}

Allan, G. J., J. Beattie, and D. J. Flint. 2004. The role of IGFBP-5 in mammary gland development and involution. Domest. Anim. Endocrinol. 27:257-266.

Baumrucker, C. R., and N. E. Erondu. 2000. Insulin-like growth factor (IGF) system in the bovine mammary gland and milk. J. Mammary Gland Biol. 5:53-64.

Baumrucker, C. R., C. A. Gibson, and F. L. Schanbacher. 2003. Bovine lactoferrin binds to insulin-like growth factor-binding protein-3. Domest. Anim. Endocrinol. 24:287-303.

Bursch, W., S. Paffe, B. Putz, G. Barthel, and R. Schulte-Hermann. 1990. Determination of the length of the histological stages of apoptosis in normal liver and in altered hepatic foci of rats. Carcinogenesis 11:847-853.

Bustin, S. A. 2002. Quantification of mRNA using real-time reverse transcription PCR (RT-PCR): Trends and problems. J. Mol. Endocrinol. 29:23-39.

Capuco, A. V., R. M. Akers, and J. J. Smith. 1997. Mammary growth in Holstein cows during the dry period: Quantification of nucleic acids and histology. J. Dairy Sci. 80:477-487.

Capuco, A. V., D. L. Wood, R. Baldwin, K. Mcleod, and M. J. Paape. 2001. Mammary cell number, proliferation, and apoptosis during a bovine lactation: Relation to milk production and effect of bST. J. Dairy Sci. 84:2177-2187.

Duan, C. M., and Q. J. Xu. 2005. Roles of insulin-like growth factor (IGF) binding proteins in regulating IGF actions. Gen. Comp. Endocrinol. 142:44-52.

Fleming, J. M., B. J. Leibowitz, D. E. Kerr, and W. S. Cohick. 2005. IGF-I differentially regulates IGF-binding protein expression in primary mammary fibroblasts and epithelial cells. J. Endocrinol. 186:165-178.

Frystyk, J., B. Dinesen, and H. Orskov. 1995. Non-competitive timeresolved immunofluorometric assays for determination of human insulin-like growth factor I and II. Growth Regul. 5:169-176.

Goodman, R. E., and F. L. Schanbacher. 1991. Bovine lactoferrin mRNA: Sequence, analysis, and expression in the mammary gland. Biochem. Biophys. Res. Commun. 180:75-84.

Knight, C. H. 2000. The importance of cell division in udder development and lactation. Livest. Prod. Sci. 66:169-176.

Knight, C. H., and C. J. Wilde. 1993. Mammary cell changes during pregnancy and lactation. Livest. Prod. Sci. 35:3-19.

Littell, R. C., G. A. Milliken, W. W. Stroup, and R. D. Wolfinger. 1996. SAS System for Mixed Models. SAS Institute, Inc., Cary, NC.

Løvendahl, P., J. Adamsen, R. Lund, and P. Lind. 2003. Technical note: Time-resolved immunofluorometric assay for growth hormone in ruminants. J. Anim. Sci. 81:1294-1299.

Løvendahl, P., and H. M. Purup. 2002. Technical note: Time-resolved fluoro-immunometric assay for intact insulin in livestock species. J. Anim. Sci. 80:191-195. 
McGuire, M. A., J. L. Vicini, D. E. Auman, and J. J. Eenhuizen. 1992. Insulin-like growth-factors and binding proteins in ruminants and their nutritional regulation. J. Anim. Sci. 70:2901-2910.

Nørgaard, J., A. Sorensen, M. T. Sørensen, J. B. Andersen, and K. Sejrsen. 2005. Mammary cell turnover and enzyme activity in dairy cows: Effects of milking frequency and diet energy density. J. Dairy Sci. 88:975-982.

Oksbjerg, N., J. S. Petersen, I. L. Sorensen, P. Henckel, M. Vestergaard, P. Ertbjerg, A. J. Moller, C. Bejerholm, and S. Stoier. 2000. Long-term changes in performance and meat quality of Danish Landrace pigs: A study on a current compared with an unimproved genotype. Anim. Sci. 71:81-92.

SAS Institute. 1999. SAS Statistical Software. Release 8.2. SAS Institute, Inc., Cary, NC.

Strudsholm, F., O. Aaes, J. Madsen, V. F. Kristensen, H. R. Andersen, T. Hvelplund, and S. Østergaard. 1999. Danish nutrient recommendations for cattle. The Danish Agricultural Advisory Centre, Report no. 84, Skejby, Denmark.

Theil, P. K., I. L. Sorensen, M. Therkildsen, and N. Oksbjerg. 2006a. Changes in proteolytic enzyme mRNAs relevant for meat quality during myogenesis of primary porcine satellite cells. Meat Sci. 73:335-343.
Theil, P. K., K. Sejrsen, W. L. Hurley, R. Labouriau, B. Thomsen, and M. T. Sørensen. 2006b. Role of suckling in regulating cell turnover and onset and maintenance of lactation in individual mammary glands of sows. J. Anim. Sci. 84:1691-1698.

Ward, P. P., E. Paz, and O. M. Conneely. 2005. Multifunctional roles of lactoferrin: A critical overview. Cell. Mol. Life Sci. 62:2540-2548.

Wareski, P., T. Motyl, Z. Ryniewicz, A. Orzechowski, B. Gajkowska, U. Wojewodzka, and T. Ploszaj. 2001. Expression of apoptosisrelated proteins in mammary gland of goat. Small Rumin. Res. 40:279-289.

Weber, M. S., S. Purup, M. Vestergaard, S. E. Ellis, J. SondergardAndersen, R. M. Akers, and K. Sejrsen. 1999. Contribution of insulin-like growth factor (IGF)-I and IGF-binding protein-3 to mitogenic activity in bovine mammary extracts and serum. J. Endocrinol. 161:365-373.

Wilde, C. J., A. J. Henderson, and C. H. Knight. 1986. Metabolic adaptations in goat mammary tissue during pregnancy and lactation. J. Reprod. Fertil. 76:289-298.

Yin, P., Q. J. Xu, and C. M. Duan. 2004. Paradoxical actions of endogenous and exogenous insulin-like growth factor-binding protein-5 revealed by RNA interference analysis. J. Biol. Chem. 279:32660-32666. 